RESEARCH ARTICLE

\title{
Assessment of GeneticVariability and Character Association in Yield Related Traits and Yellow Vein Mosaic Virus Disease Resistance in Okra (Abelmoschus esculentus L. Moench)
}

\author{
Gurve V $\mathbf{R}^{1^{*}}$, Swarna Priya $R^{1}$, Pugalendhi $L^{2}$, Karthikeyan $G^{3}$, Gnanam $R^{4}$ and Kalaiyarasi $R^{5}$ \\ *1Department of Vegetable Science, Horticultural College and Research Institute, \\ Tamil Nadu Agricultural University, Coimbatore-641 003, Tamil Nadu, India. \\ ${ }^{2}$ Horticultural College and Research Institute, Tamil Nadu Agricultural University, Coimbatore-641 003, Tamil Nadu, India. \\ ${ }^{3}$ Department of Plant Pathology, Agricultural College and Research Institute, \\ Tamil Nadu Agricultural University, Coimbatore-641 003, Tamil Nadu, India. \\ ${ }^{4}$ Department of Plant Molecular Biology and Bioinformatics, Agricultural College and Research Institute, \\ Tamil Nadu Agricultural University, Coimbatore-641 003, Tamil Nadu, India. \\ ${ }^{5}$ Department of Genetics and Plant Breeding, Centre for Plant Breeding and Genetic, Agricultural College and Research Institute, \\ Tamil Nadu Agricultural University, Coimbatore-641 003, Tamil Nadu, India.
}

\begin{abstract}
Okra is India's most widely grown tropical and subtropical vegetable crop. Despite widespread cultivation, crop yield and productivity remain subpar. Yellow vein mosaic virus (YVMV) disease is a serious threat to Indian okra production, causing yield losses ranging from 17.09 to 96.49 per cent. In this context, the present study was aimed to assess the variability and character association of 74 elite germplasm accessions for thirteen quantitative and quality traits. High phenotypic and genotypic coefficient of variation (PCV and GCV) were observed among all evaluated traits except fruit diameter, which showed a moderate PCV and GCV. All traits had high heritability and high genetic advance, implying that the heritability was most likely due to additive gene effects. Direct selection of these traits would be advantageous for okra improvement, especially in developing a YVMV resistant genotype. Fruit yield per plant exhibited a significant and positive genotypic as well as phenotypic correlation with fruit weight, fruit length, peroxidase activity, polyphenol activity, fruit diameter, total phenolic content and plant height, whereas node at which the first flower appeared and YVMV were negatively correlated to fruit yield per plant. Correlation studies indicated YVMV resistance towards high total phenolic content, polyphenol oxidase, and peroxidase. The high positive direct effects on fruit yield per plant were observed for fruit weight followed by number of fruit per plant and total phenolic content. This study revealed that simultaneous selection of these traits can help in increasing yield and YVMV resistance.
\end{abstract}

Keywords: Okra; Genetic variability; Correlation; Path analysis; YVMV

\section{INTRODUCTION}

Okra (Abelmoschus esculentus L. Moench) is a well-known and economically valuable tropical and subtropical vegetable crop. It is a member of the Malvaceae family and has a chromosome number of $2 n=130$. It is rich in vitamins and minerals, calcium, potassium, fibre, and iron making it a nutrient-dense food (IBPGR, 1990). It is India's most frequently cultivated and popular vegetable crop ranking first in the world production with 60.03 lakh tonnes with aproductivity of 12.0 tonnes ha-1 (Anon. 2017). The okra cultivation in India is influenced by various biotic and abiotic factors. The most serious disease caused by biotic factors is the Yellow vein mosaic virus disease, which is transmitted by whitefly (Bemisia tabaci Genn) (Khade et al.,2020). It lowered fruit production by $17.09 \%$ to $96.49 \%$ (Jamir et al., 2020). This disease is caused by a variety of monopartite and bipartite begomoviruses and their satellite DNA poses a significant threat to okra cultivation (Venkataravanappa et al., 2016).

Plant genetic resources are vital in ensuring global food security in the future. To acquire elite germplasm, phenotypic selection of desirable traits with a high GCV and PCV, high heritability, and a high genetic advance is essential in order to use them in successive breeding programmes (Yadav et al., 2019). A positive or negative association between 
two traits is important for plant breeders to generate new varieties with superior yielding characteristics (Priyanka et al.,2018). According to Dewey and Lu (1959), the path coefficient analysis was employed to determine the cause and effect relationship by partitioning the correlation coefficient into direct and indirect effects of traits on the dependent variable. Understanding the relationship between yield and other traits is critical to improving any crop. Therefore, the current study was carried out to assess the variability and investigate the relationship between the yield contributing traits and YVMV resistance in the available okra accessions, which will benefit the selection of valuable genotypes for future breeding programmes.

\section{MATERIAL AND METHODS}

The current research was carried out at the Department of Vegetable Science, Horticultural College and Research Institute, Tamil Nadu Agricultural University (TNAU), Coimbatore, India. 74 elite okra accessions were collected from various geographical regions, National Institutes, and State Agricultural Universities of India. The experiment was divided into three replications using a randomised block design (RBD) with a spacing of $60 \times 45 \mathrm{~cm}$. All production techniques were implemented in accordance with the TNAU crop production manual. Plant height $(\mathrm{cm})$, node at which the first flower appears, number of primary branches per plant, fruit length $(\mathrm{cm})$, fruit diameter $(\mathrm{cm})$, fruit weight (g), number of ridges on fruit, number of fruits per plant, fruit yield per plant (g) were all measured on ten randomly selected plants. Sadasivam and Manickam's (1991) technique was used to determine quality traits such as total phenolic content, peroxidase activity, and polyphenol oxidase. Using an infector row technique, the field experiment was carried out during the summer season, during the peak pressure of the vector Bemisia tabaci. The healthy-to-vulnerable plant ratio was 3:1. To test for YVMV susceptibility, Arka Anamika and Parbhani Kranti were used. No chemicals were sprayed on the crops during the growing season. Natural pressure was allowed to run at full throttle, allowing diseases to spread at breakneck speed. From the date of sowing to crop harvesting, fortnightly observations on YVMV symptoms were made on average. The following disease severity scale for YVMV as adopted by Das et al. (2013) was used in study.

\begin{tabular}{cl}
\hline $\begin{array}{c}\text { Disease } \\
\text { Severity Scale }\end{array}$ & \multicolumn{1}{c}{ Symptoms } \\
\hline 0 & No disease \\
1 & up to 15\% of leaf area affected \\
3 & $30 \%-45 \%$ of leaf area affected \\
5 & $45 \%-60 \%$ of leaf area affected \\
7 & greater than $60 \%$ of leaf area affected \\
\hline
\end{tabular}

The following scale were used for evaluation of resistance and the susceptible reaction of the genotypes to YVMV disease by Percent Disease Index (PDI).

A Resistant (R) PDI $\leq 10 \%$,

B Moderately resistant (MR) PDI 11 - 15\%

C Moderately susceptible (MS) PDI 16 - 45\%

D Highly susceptible (HS) PDI > $45 \%$

The incidence of the YVMV disease was calculated by the following formula:

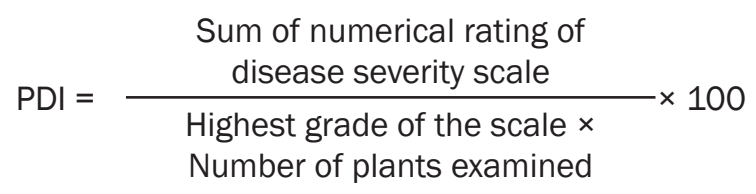

The mean data was subjected to statistical analysis using the software INDOSTAT. The analysis of variance and summary statistics were computed in accordance with Panse and Sukathme (1967). Phenotypic, genotypic coefficients of variation (PCV and GCV), heritability $\left(\mathrm{h}^{2}\right)$ (broad sense) were calculated as per Burton and Devane, (1953) and Allard (1960). Phenotypic and genotypic correlations were calculated as per Falconer (1981). Heritability and genetic advancement were classified as low, medium, and high, according to Johnson et al. (1955). The path coefficient analysis proposed by Wright (1921) and refined by Dewey and Lu (1959) was used to compute various traits' direct and indirect contributions to yield. The direct and indirect effects were measured using the Lenka and Mishra (1973) scale.

\begin{tabular}{lccc}
\hline Scale & $\begin{array}{c}\text { GCV and } \\
\text { PCV }\end{array}$ & $\begin{array}{c}\text { Heritability } \\
\left(\boldsymbol{h}^{\mathbf{2}}\right)\end{array}$ & $\begin{array}{c}\text { Genetic } \\
\text { Advance }\end{array}$ \\
\hline Low & $0-10 \%$ & $0-30 \%$ & $0-10 \%$ \\
Moderate & $10-20 \%$ & $30-60 \%$ & $10-20 \%$ \\
High & $>20 \%$ & $>60 \%$ & $>20 \%$ \\
\hline \multicolumn{4}{c}{ Scale } \\
\multicolumn{4}{c}{ Direct and Indirect effects } \\
\hline Very high & \multicolumn{3}{c}{$>1.000$} \\
High & $0.30-0.99$ \\
Moderate & $0.20-0.29$ \\
Low & $0.10-0.19$ \\
Negligible & $0.00-0.09$ \\
\hline
\end{tabular}

\section{RESULTS AND DISCUSSION}

Analysis of variance was performed on the data collected from all 74 genotypes and a significant difference was observed in all studied characters among genotypes, revealing that there is adequate variability in the experimental material to allow for selection and the possibility of enhancing yield

$107|10-12| 2$ 
and yield-related attributes for crop improvement (Table 1).

Table 1. Mean performance of okra genotypes for yield and yield attributing traits and YVMV resistance

\begin{tabular}{ccccc}
\hline \multirow{2}{*}{ Traits } & Mean & \multicolumn{2}{c}{ Range } & CV \\
\cline { 3 - 4 } & & Minimum & Maximum & \\
\hline PH & 111.30 & 39.45 & 191.71 & 7.76 \\
NFF & 4.19 & 2.88 & 7.87 & 6.32 \\
NPB & 3.51 & 1.36 & 19.89 & 12.21 \\
FL & 14.53 & 2.96 & 25.43 & 3.83 \\
FD & 2.00 & 1.28 & 3.58 & 4.28 \\
FW & 17.51 & 0.69 & 28.33 & 6.98 \\
NR & 5.70 & 5.00 & 9.00 & 9.48 \\
NFP & 32.56 & 9.05 & 104.78 & 6.47 \\
FY & 468.83 & 5.75 & 868.62 & 5.67 \\
TPC & 0.76 & 0.39 & 2.70 & 2.83 \\
POD & 1.97 & 0.70 & 4.43 & 1.52 \\
PPO & 1.44 & 3.25 & 0.81 & 5.25 \\
YVMV & 30.23 & 0 & 84.28 & 5.50 \\
\hline & & & & \\
\hline
\end{tabular}

\section{Phenotypic and genotypic coefficient of variation}

Among the all traits studied, high PCV and GCV were observed for a number of primary branches per plant, total phenolic content, YVMV, number of fruits per plant, polyphenol oxidase, peroxidase activity, fruit yield per plant, fruit weight (g), plant height $(\mathrm{cm})$, node at which the first flower appears, fruit length $(\mathrm{cm})$ and number of ridges on fruit (Table 2). However, moderate PCV and GCV were recorded in fruit diameter $(\mathrm{cm})$. The result revealed that the difference between the PCV and GCV was minor for all traits studied, indicating that the environment would have little influence on the expression of characters and they could be improved by applying simple selection pressure to these characters during the early generation. A high PCV in combination with a high GCV showed that there was more variation for specific traits in the population. Thus, by employing a simple selection approach, this available variation could be used in the early generation. Similar results were reported by Sravanthi et al. (2021), Hamisu et al. (2021) and Nuksungla et al. (2020).

\section{Heritability and genetic advance}

Almost every trait investigated in this study had a high degree of heritability, ranging from 89.28 percent (number of ridges on fruit) to 99.93 percent (total phenolic content) (Table 2). Considering that the environment had the least effect on all of the traits, showed that selecting for such traits could be advantageous. In conjunction with the heritability estimate, the genetic advance would allow a breeder to reach more conclusions than would be possible with just the heritability estimate alone. In the current study, the predicted genetic advance as a percentage of the mean was found to be high for all variables studied, ranging from 33.79 percent (fruit diameter) to 163.90 percent (number of primary branches per plant) (Table 2). All of the traits studied had high heritability as well as high genetic advance, suggesting that the heritability was most likely due to additive gene effects. It is possible that selection would be effective for all of the traits studied. As a result, direct selection based on these characteristics will be effective for okra improvement, particularly for developing a genotype with YVMV resistance. Similar findings were reported by Sravanthi et al. (2021), Melaku et al. (2020), Walling et al. (2020), Rana et al. (2020) and Patra et al. (2018).

Table 2. Variance estimates of yield and its contributing traits and YVMV resistance in okra genotypes

\begin{tabular}{llllll}
\hline Traits & PCV & GCV & $\mathbf{h}^{2}$ & GA & GAM \\
\hline PH & 27.28 & 26.72 & 95.96 & 60.01 & 53.92 \\
NFF & 24.71 & 24.30 & 96.73 & 2.06 & 49.24 \\
NPB & 80.49 & 80.02 & 98.85 & 5.76 & 163.90 \\
FL & 23.64 & 23.49 & 98.69 & 6.99 & 48.07 \\
FD & 16.94 & 16.67 & 96.81 & 0.68 & 33.79 \\
FW & 33.07 & 32.70 & 97.77 & 11.66 & 66.61 \\
NR & 20.47 & 20.01 & 89.28 & 2.15 & 37.64 \\
NFP & 45.35 & 45.12 & 98.98 & 30.11 & 92.47 \\
FY & 35.19 & 34.96 & 98.70 & 335.47 & 71.56 \\
TPC & 75.34 & 75.31 & 99.93 & 1.18 & 155.08 \\
POD & 39.05 & 39.04 & 99.92 & 1.59 & 80.39 \\
PPO & 43.04 & 42.88 & 99.26 & 1.26 & 88.00 \\
YVMV & 71.45 & 71.34 & 99.70 & 44.36 & 146.74 \\
\hline
\end{tabular}

$\mathrm{PH}$ - Plant height (cm), NFF - Node at which the first flower appears, NPB - Number of primary branches per plant, FL Fruit length (cm), FD -Fruit diameter (cm), FW - fruit weight (g), NR - Number of ridges on fruit, NFP - Number of fruit per plant, FY - Fruit yield per plant (g), TPC - Total phenolic content, POD - Peroxidase activity, PPO - Polyphenol oxidase and YVMV - Yellow vein mosaic virus

\section{Phenotypic and Genotypic correlation}

In general, yield and yield components are polygenic in nature and are subject to different amounts of non-heritable variation. In okra, fruit yield per plant is the result of the interaction of a number of associated characters. As a result, selection should be made based on component characters after determining their correlation with fruit yield per plant. The present investigation observed that the phenotypic correlation coefficient is greater than the genotypic correlation coefficient for the characters studied, which indicates a significant 
inherent among the variables (Samiksha et al.,2021) (Table 3). A strong positive relationship between character and yield may be attributed to linkage and pleiotropy (Sparque, 1966). In the present study, fruit yield per plant exhibited a significant and positive genotypic as well as phenotypic correlation with fruit weight, fruit length, peroxidase activity, polyphenol activity, fruit diameter, total phenolic content, and plant height. On the other hand, the node at which first flower appeared and YVMV were negatively correlated to fruit yield per plant. However, YVMV exhibited a significant and positive genotypic and phenotypic correlation with the plant height while, total phenolic content, polyphenol oxidase, peroxidase, and the number of fruit per plant were negatively correlated with YVMV, indicating that high total phenolic content, polyphenol oxidase and peroxidase result into YVMV resistance. These findings indicated that selecting these component traits will be effective in increasing okra fruit yield and YVMV resistance. Similar findings were given by Wallin et al. (2020), Raval et al. (2019), Yadav et al. (2019), Patra et al. (2018) and Singh et al. (2017).

Table 3. Genotypic and Phenotypic correlation for yield and its contributing traits and YVMV resistance in okra genotypes

\begin{tabular}{|c|c|c|c|c|c|c|c|c|c|c|c|c|c|c|}
\hline & & PH & NFF & NPB & $\mathbf{F L}$ & FD & FW & NR & NFP & TPC & POD & PPO & YVMV & FY \\
\hline \multirow[t]{2}{*}{ PH } & rg & 1 & & & & & & & & & & & & \\
\hline & $\mathrm{rp}$ & 1 & & & & & & & & & & & & \\
\hline \multirow[t]{2}{*}{ NFF } & rg & -0.08 & 1 & & & & & & & & & & & \\
\hline & $\mathrm{rp}$ & -0.083 & 1 & & & & & & & & & & & \\
\hline \multirow[t]{2}{*}{ NPB } & rg & 0.016 & $0.571 * *$ & 1 & & & & & & & & & & \\
\hline & $\mathrm{rp}$ & 0.018 & $0.535 * *$ & 1 & & & & & & & & & & \\
\hline \multirow[t]{2}{*}{$\mathbf{F L}$} & rg & 0.043 & -0.476 ** & $-0.552 * *$ & 1 & & & & & & & & & \\
\hline & $\mathrm{rp}$ & 0.044 & $-0.450 * *$ & $-0.542 * *$ & 1 & & & & & & & & & \\
\hline \multirow[t]{2}{*}{ FD } & rg & $-0.179 *$ & 0.09 & $0.322 * *$ & 0.154 & 1 & & & & & & & & \\
\hline & $\mathrm{rp}$ & $-0.175 *$ & 0.073 & $0.305 * *$ & 0.15 & 1 & & & & & & & & \\
\hline \multirow[t]{2}{*}{ FW } & rg & -0.013 & $-0.382 * *$ & $-0.445 * *$ & $0.728 * *$ & $0.371 * *$ & 1 & & & & & & & \\
\hline & $\mathrm{rp}$ & -0.015 & $-0.359 * *$ & $-0.437 * *$ & $0.712 * *$ & $0.346 * *$ & 1 & & & & & & & \\
\hline \multirow[t]{2}{*}{ NR } & rg & $-0.436 * *$ & $0.277 * \star$ & 0.079 & 0.018 & $0.373 * *$ & $0.293 * *$ & 1 & & & & & & \\
\hline & $\mathrm{rp}$ & $-0396 * *$ & $0.230 * *$ & 0.082 & 0.19 & $0.309 * *$ & $0.261 * *$ & 1 & & & & & & \\
\hline \multirow[t]{2}{*}{ NFP } & rg & $0.234 * *$ & $0.411 * *$ & $0.755^{* *}$ & $-0.395 * *$ & 0.087 & $-0.423 * *$ & $-0.318 * *$ & 1 & & & & & \\
\hline & $\mathrm{rp}$ & $0.222 * *$ & $0.395 * *$ & $0.744 * *$ & $-0.384 * *$ & 0.084 & $-0.406 * *$ & $-0.282 * *$ & 1 & & & & & \\
\hline \multirow[t]{2}{*}{ TPC } & rg & -0.13 & 0.093 & 0.075 & -0.037 & 0.075 & -0.107 & $-0.243 * *$ & $0.233 * *$ & 1 & & & & \\
\hline & $\mathrm{rp}$ & -0.123 & 0.09 & 0.074 & -0.036 & 0.073 & -0.104 & $-0.218 * *$ & $=0.230 * *$ & 1 & & & & \\
\hline \multirow[t]{2}{*}{ POD } & $\mathrm{rg}$ & -0.116 & -0.044 & -0.024 & 0.091 & 0.056 & 0.007 & $-0.276 * *$ & $0.186 *$ & $0.959 * *$ & 1 & & & \\
\hline & $r p$ & -0.111 & -0.042 & -0.023 & 0.09 & 0.054 & 0.005 & $-0.247 * *$ & $0.184 *$ & $0.958 * *$ & 1 & & & \\
\hline \multirow[t]{2}{*}{ PPO } & $\mathrm{rg}$ & -0.138 & -0.017 & 0.022 & 0.052 & 0.123 & -0.029 & $-0.221 * *$ & . $0.199 *$ & $0.954 * *$ & $0.956 * *$ & 1 & & \\
\hline & $\mathrm{rp}$ & -0.13 & -0.015 & 0.021 & 0.051 & 0.119 & -0.024 & $-0.219 * *$ & $0.199 *$ & $0.946 * *$ & $0.949 * *$ & 1 & & \\
\hline \multirow[t]{2}{*}{ YVMV } & rg & 0.254 ** & $-0.182 *$ & $-0.196 *$ & 0.129 & -0.089 & $0.186 *$ & 0.057 & $-0.218 * *$ & $-0.649 * *$ & $-0.590 * *$ & $-0.634 * *$ & 1 & \\
\hline & $\mathrm{rp}$ & $0.244 * *$ & $-0.178 *$ & $-0.192 *$ & 0.126 & -0.09 & $0.184 *$ & 0.055 & $-0.214 * *$ & $-0.647 * *$ & $-0.588 * *$ & $-0.628 * *$ & 1 & \\
\hline \multirow[t]{2}{*}{ FY } & rg & 0.227 ** & $-0.193 *$ & -0.139 & $0.508 * *$ & $0.306 * *$ & $0.636 * *$ & -0.135 & $0.168^{*}$ & $0.281 * *$ & $0.349 * *$ & $0.324 * *$ & -0.087 & 1 \\
\hline & $\mathrm{rp}$ & $0.214 * *$ & $-0.184 *$ & -0.137 & $0.498 * *$ & $0.298 * *$ & $0.611 * *$ & -0.116 & $0.173^{*}$ & 0.277 ** & $0.344 * *$ & $0.317 * *$ & -0.085 & 1 \\
\hline
\end{tabular}

* Significant at $5 \%$ level, **Significant at $1 \%$ level

PH - Plant height (cm), NFF - Node at which the first flower appears, NPB - Number of primary branches per plant, FL - Fruit length (cm), FD -Fruit diameter (cm), FW - fruit weight (g), NR - Number of ridges on fruit, NFP - Number of fruit per plant, FY - Fruit yield per plant (g), TPC - Total phenolic content, POD - Peroxidase activity, PPO - Polyphenol oxidase and YVMV - Yellow vein mosaic virus

\section{Direct and Indirect effects}

Path coefficient analysis (Table 4 and Figure 2) is a useful technique for partitioning the correlation coefficient into direct and indirect effects, which helps in explaining the relative importance of each trait as well as its reliability in selection. In the present study, the highest positive direct effects on fruit yield per plant were observed for fruit weight $(0.7918)$ followed by a number of fruit per plant (0.6017) and total phenolic content (0.3996) while, plant height (0.1104) observed low direct effect. However, fruit diameter (0.0774), fruit length (0.04360), polyphenol oxidase (0.0423) and node at which the first flower appeared (0.0273) were observed negligible positive direct effects on fruit yield per plant. The number of primary branches per plant (-0.2937) and peroxidase activity (-0.2402) were observed to have moderate negative direct effects while low in number of ridges on fruit (-0.1). The YVMV (-0.0326) exhibited negligible negative direct effects on fruit yield per plant (Figure 1). As a result of this study, it was observed that

$107 \mid 10-12$ | 4 
direct selection based on these traits can help in enhancing yield, selection of early-type, and YVMV resistance. These findings were supported by Yadav et al. (2019) and Patra et al. (2018).

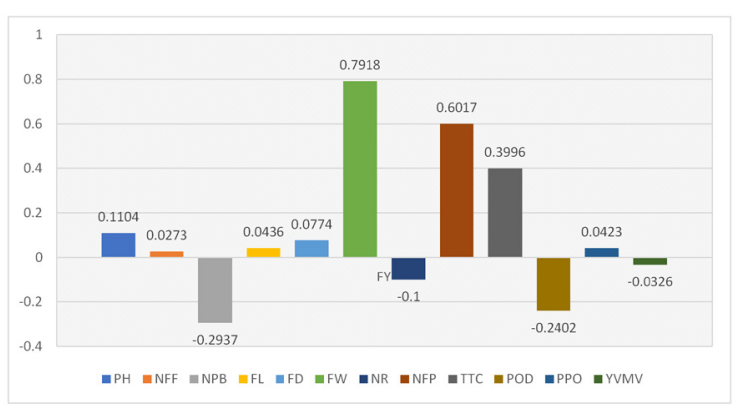

Figure 1. Correlation coefficient of each trait showing positive and negative direct effects on fruit yield per plant for thirteen quantitative and quality traits of okra

$\mathrm{PH}$ - Plant height $(\mathrm{cm})$, NFF - Node at which the first flower appears, NPB - Number of primary branches per plant, FL - Fruit length (cm), FD -Fruit diameter (cm), FW - fruit weight (g), NR - Number of ridges on fruit, NFP - Number of fruit per plant, FY Fruit yield per plant (g), TPC - Total phenolic content, POD - Peroxidase activity, PPO - Polyphenol oxidase and YVMV - Yellow vein mosaic virus

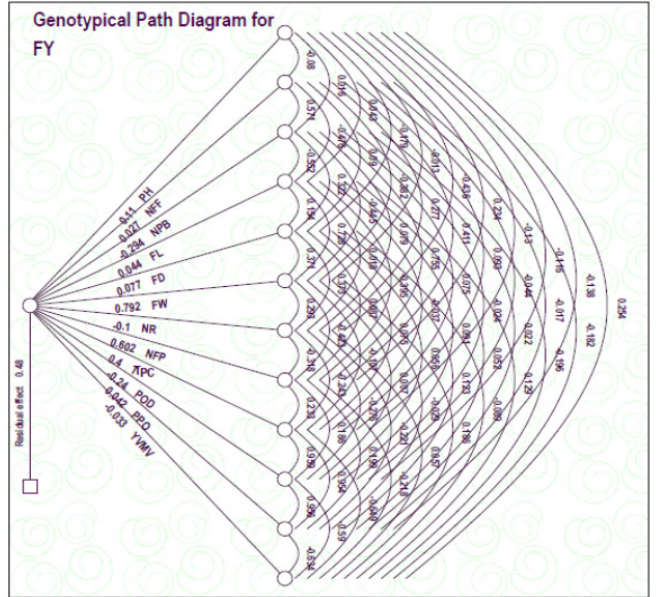

Figure 2. Genotypical path diagram showing direct and indirect effects on fruit yield per plant

$\mathrm{PH}$ - Plant height (cm), NFF - Node at which the first flower appears, NPB - Number of primary branches per plant, FL - Fruit length (cm), FD -Fruit diameter (cm), FW - fruit weight (g), NR - Number of ridges on fruit, NFP - Number of fruit per plant, FY Fruit yield per plant (g), TPC - Total phenolic content, POD - Peroxidase activity, PPO - Polyphenol oxidase and YVMV - Yellow vein mosaic virus

Table 4. Direct and indirect effects for thirteen quantitative and quality traits of okra genotypes

\begin{tabular}{lccccccccccccc}
\hline & PH & NFF & NPB & FL & FD & FW & NR & NFP & TPC & POD & PPO & YVMV \\
\hline PH & $\mathbf{0 . 1 1 0 4}$ & -0.0022 & -0.0047 & 0.0019 & -0.0138 & -0.0103 & 0.0436 & 0.1405 & -0.0519 & 0.0279 & -0.0059 & -0.0083 \\
NFF & -0.0089 & $\mathbf{0 . 0 2 7 3}$ & -0.1677 & -0.0207 & 0.007 & -0.3027 & -0.0277 & 0.2476 & 0.037 & 0.0106 & -0.0007 & 0.0059 \\
NPB & 0.0018 & 0.0156 & -0.2937 & -0.0241 & 0.0249 & -0.3524 & -0.0079 & 0.454 & 0.0299 & 0.0058 & 0.0009 & 0.0064 \\
FL & 0.0047 & -0.013 & 0.1622 & 0.0436 & 0.0119 & 0.5765 & -0.0018 & -0.2377 & -0.0148 & -0.0218 & 0.0022 & -0.0042 \\
FD & -0.0197 & 0.0025 & -0.0946 & 0.0067 & 0.0774 & 0.2937 & -0.0373 & 0.0526 & 0.0301 & -0.0133 & 0.0052 & 0.0029 \\
FW & -0.0014 & -0.0104 & 0.1307 & 0.0317 & 0.0287 & 0.7918 & -0.0293 & -0.2544 & -0.0426 & -0.0016 & -0.0012 & -0.0061 \\
NR & -0.0482 & 0.0076 & -0.0233 & 0.0008 & 0.0289 & 0.2322 & -0.1 & -0.1912 & -0.0971 & 0.0664 & -0.0094 & -0.0019 \\
NFP & 0.0258 & 0.0112 & -0.2216 & -0.0172 & 0.0068 & -0.3347 & 0.0318 & 0.6017 & 0.0931 & -0.0446 & 0.0084 & 0.0071 \\
TPC & -0.0143 & 0.0025 & -0.022 & -0.0016 & 0.0058 & -0.0844 & 0.0243 & 0.1402 & $\mathbf{0 . 3 9 9 6}$ & -0.2304 & 0.0404 & 0.0211 \\
POD & -0.0128 & -0.0012 & 0.0071 & 0.004 & 0.0043 & 0.0053 & 0.0276 & 0.1118 & 0.3833 & -0.2402 & 0.0404 & 0.0192 \\
PPO & -0.0153 & -0.0005 & -0.0064 & 0.0023 & 0.0095 & -0.0227 & 0.0221 & 0.12 & 0.3812 & -0.2296 & $\mathbf{0 . 0 4 2 3}$ & 0.0206 \\
YVMV & 0.028 & -0.005 & 0.0577 & 0.0056 & -0.0069 & 0.1474 & -0.0057 & -0.1309 & -0.2594 & 0.1417 & -0.0268 & -0.0326 \\
\hline
\end{tabular}

Residual effect $=0.48$, Direct effect: Bold diagonal values, Indirect effect: Non diagonal values, PH - Plant height (cm), NFF - Node at which the first flower appears, NPB - Number of primary branches per plant, FL - Fruit length (cm), FD -Fruit diameter (cm), FW - fruit weight (g), NR - Number of ridges on fruit, NFP - Number of fruit per plant, FY - Fruit yield per plant (g), TPC - Total phenolic content, POD - Peroxidase activity, PPO - Polyphenol oxidase and YVMV - Yellow vein mosaic virus

\section{CONCLUSION}

The current study found that all analysed traits had a high PCV and GCV, except for fruit diameter, which had a moderate PCV and GCV. All traits demonstrated a high heritability in combination with high genetic advances, indicating that the heritability was most likely due to additive gene effects and that direct selection based on these traits would be effective for okra improvement, particularly for developing a genotype resistant to YVMV. The association study revealed a strong and significant genotypic and phenotypic correlation between fruit yield per plant with fruit weight, fruit 
length, peroxidase activity, polyphenol activity, fruit diameter, total phenolic content, and plant height. On the other hand, the node at which the first flower appeared and YVMV were negatively correlated with fruit yield per plant. The path analysis study found that the highest positive direct effects on fruit yield per plant were observed for fruit weight $(0.7918)$ followed by number of fruit per plant (0.6017) and total phenolic content (0.3996) while, a number of primary branches per plant $(-0.2937)$ and peroxidase activity $(-0.2402)$ was observed to have moderate negative direct effects on fruit yield per plant. This study revealed that simultaneous selection of these traits can help in increasing yield and YVMV resistance.

\section{FUNDING AND ACKNOWLEDGMENT}

The authors would like to thank NBPGR, New Delhi, VNMKV, Parbhani, and TNAU, Coimbatore for providing the okra accessions, as well as UGCNFOBC for providing the fellowship during the study.

\section{Ethics statement}

No specific permits were required for the described field studies because no human or animal subjects were involved in this research.

\section{Consent for publication}

All the authors agreed to publish the content.

\section{Competing interests}

There were no conflict of interest in the publication of this content

\section{REFERENCES}

Allard R.W. 1960. Principles of Plant Breeding. John Wiley and Sons Inc. New York., 485.

Anonymous, 2017. Food and Agriculture Organization (FAO). (ON1407).

Burton, G.W. and Devane, D.E., 1953. Estimating heritability in tall fescue (Festuca arundinacea) from replicated clonal material. Agronomy journal., 45(10): 478-481.

Das, S., Chattopadhyay, A., Dutta, S., Chattopadhyay, S.B. and Hazra, P., 2013. Breeding okra for higher productivity and yellow vein mosaic tolerance. Int. J. Veg. Sci.,19(1) :58-77.

Dewey, D.R. and Lu, K., 1959. A Correlation and Path-Coefficient Analysis of Components of Crested Wheatgrass Seed Production. Agronomy journal., 51(9): 515-518.

Falconer DS. 1981. Introduction to Quantitative Genetics. 2nd ed. Longman, London.

Hamisu, A., Magashi A.I., Dawaki K.D., Abdullahi, A., Munkaila, N., Dankano, I. 2021. Genetic variability studies among okra (Abelmoschus Esculentus (L.) Moench) varieties grown in sudan savannah agroecological zone of Nigeria. Int. j. agric. environ. res., 07(3): 437-448.
International Board for Plant Genetic Resources IBPGR. 1990. Report on International Workshop on Okra Genetic resources held at the National bureau for Plant Genetic Resources, New Delhi, India.

Jamir, I., Mandal, A.K., Devi, A.P., Bhattacharjee, T., Maurya, P.K., Dutta, S., Chattopadhyay, A., Pramanik, K. and Banik, S. 2020. Screening of genotypes against viral diseases and assessment of yield loss due to yellow vein mosaic virus in okra grown in the eastern part of India. Indian Phytopathol., 73(1): 125-133.

Johnson, H.W., Robinson, H.F. and Comstock, R.E., 1955. Estimates of genetic and environmental variability in soybeans. Agronomy journal., 47(7): 314-318.

Khade, Y.P., Kumar, R. and Yadav, R.K., 2020. Genetic control of yellow vein mosaic virus resistance in okra (Abelmoschus esculentus). Indian J. Agric. Sci.,90(3): 606-9.

Lenka, D. and Mishra, B., 1973. Path coefficient analysis of yield in rice varieties. Indian J. Agric. Sci., 43(4): 376.

Melaku AB, Mohamed W, Kumar V. 2020. Variability, heritability and genetic advance in indigenous and exotic okra [Abelmoschus esculentus (L.) moench] genotypes for yield and yield related traits at Dire Dawa, Eastern Ethiopia. MOJ Eco Environ Sci.,5(4):164-169.

Nuksungla W., Kanaujia S.P., Pauline A., Sharma M.B., Chubatemsu 0.2020, Genetic Variability and Correlation Studies in okra (Abelmoschus Esculentus I. Moench) Genotypes Under Foothill Conditions of Nagaland. Int J Recent Sci Res., 11(02): 37651-37654.

Panse, V.G. and Sukathme, P.V. 1967. Statistical Method for Agricultural Workers. ICAR, New Delhi., 381.

Patra, N. R., Nayak, N. J., and Baisakh, B. 2018. Evaluation of Elite Genotypes for YVMV Resistance in Okra [Abelmoschus esculentus (L.) Moench]. Int.J.Curr.Microbiol.App.Sci., 7(12): 594-608.

Priyanka, D.V., Reddy, M.T., Begum, H., Sunil, N. and Jayaprada, M., 2018. Studies on genetic variability, heritability and genetic advance in genotypes of okra [Abelmoschus esculentus (L.) moench]. Int. J. Curr. Microbiol. App. Sci., 7(5): 401-411.

Rana A., Singh S., Bakshi M., and Singh S. K., 2020. Studied on genetic variability, correlation and path analysis for morphological, yield and yield attributed traits in okra [Abelmoschus esculentus (L.) Monech]. Int. J. Agricult. Stat. Sci., 16(1): 387-394.

Raval V., Patel A. I., Vashi J.M., and Chaudhari B.N., 2019.Correlation and Path Analysis Studies in Okra (Abelmoschus esculentus (L.) Moench). ASAG.,3(2): 65-70.

Sadasivam S. and A. Manickam. 1991. Biochemical methods for agricultural science. Willey eastern limited.

Samiksha, R. S. Verma, S. K. Verma, S. A., Kumar, S. and Maurya, S. K. 2021. Studies on Correlation 
and Path Coefficient Analysis in Okra [Abelmoschus esculents (L.) Moench]. Int.J.Curr.Microbiol.App. Sci.,10(3): 277-284.

Singh N, Singh D K, Pandey P, Panchbhaiya A and Rawat M. 2017. Correlation and Path Coefficient Studies in Okra [Abelmoschus esculentus (L.) Moench]. Int.J.Curr.Microbiol.App.Sci., 6(7): 1096-101.

Sparque GF. 1966. Quantitative genetics in plant improvement in plant Breeding. K.J. Frey Edition, 315-354.

Sravanthi, U., Prabhakar, B.N., Saidaiah, P., Rao, A.M., Narayana, D.L. and Sathish, G., 2021. Studies on genetic variability in okra (Abelmoschus esculentus (L.) Moench). J. Pharm. Innov., 10(11): 151-155.

Venkataravanappa V., Reddy C.N.L., Chauhan N. S., Singh B., Sanwal S. K. and Krishna Reddy M. 2016. Nucleotide sequencing and an improved diagnostic for screening okra (Abelmoschus esculentus L.) genotypes for resistance to a newly described begomovirus in India. J. Hortic. Sci. Biotechnol., 91(2): 161-168.

Walling, N., Kanaujia S.P., Alila, P., Sharma, M.B. and Ozukum, C., 2020. Genetic variability and correlation studies in okra (Abelmoschus esculentus I. Moench) genotypes under foothill conditions ofNagaland. Int. J. Recent Sci. Res., 11(2): 37651-37654.

Wright, S. 1921. Correlation and causation. J. Agric. Res., 20: 557-587.

Yadav, R.K., Mahesh, B. and Suman, L., 2019. Studies of genetic variability and association of yield traits and YVMV disease in Abelmoschus species. Indian J. Agric. Sci., 89(4): 688-694. 